\title{
Studi Penurunan Kadar Logam Fe dan Co pada Limbah Cair dengan Sistem Purifikasi Berbasis Adsorben Nanopartikel Magnetik $\mathrm{Fe}_{3} \mathrm{O}_{4}$
}

\author{
Dewi Sartika, Fitri Puji A dan Edi Suharyadi* \\ Jurusan Fisika, Fakultas MIPA, Universitas Gadjah Mada, Yogyakarta, Indonesia Sekip Utara PO BOX BLS.21 Yogyakarta 55281, Indonesia \\ *Corresponding Author : esuharyadi@ugm.ac.id
}

\begin{abstract}
Abstrak - Proses purifikasi limbah cair mengandung logam Fe dan Co dengan menggunakan adsorben nanopartikel magnetik $\mathrm{Fe}_{3} \mathrm{O}_{4}$ berukuran $14,5 \mathrm{~nm}$ telah dilakukan. Pada konsentrasi $\mathrm{Fe}_{3} \mathrm{O}_{4} \mathrm{O}, 01 \mathrm{~g} / \mathrm{ml}$, kadar logam Co dan $\mathrm{Fe}$ mengalami penurunan lebih besar daripada konsentrasi $\mathrm{Fe}_{3} \mathrm{O}_{4} 0,008 \mathrm{~g} / \mathrm{ml}$, yaitu masing-masing sebesar $71 \%$ dan 99\%. Penurunan kadar logam Co dan Fe juga terserap secara efektif oleh adsorben dengan ukuran partikel 11,5 nm daripada yang berukuran 14,5 $\mathrm{nm}$ yaitu masingmasing Co dan Fe sebesar 99,855\% dan 100\%. Pada proses adsorpsi kedua (amplifikasi) kadar logam Co dan Fe mengalami penurunan secara maksimal yaitu sebesar $100 \%$.
\end{abstract}

Kata Kunci: Purifikasi, Absorpsi, dan Adsorben $\mathrm{Fe}_{3} \mathrm{O}_{4}$

Abstract - Purification of wastewater contained metal Co and Fe by using absorben nanoparticle magnetic $\mathrm{Fe}_{3} \mathrm{O}_{4}$ with $14,5 \mathrm{~nm}$ particle size has done. At concentration of $\mathrm{Fe}_{3} \mathrm{O}_{4} 0,01 \mathrm{~g} / \mathrm{ml}$, Co and $\mathrm{Fe}$ decreased greater than concentration $\mathrm{Fe}_{3} \mathrm{O}_{4} 0,008 \mathrm{~g} / \mathrm{ml}$, they are $71 \%$ and $99 \%$, respectively. Reduction metals of Co and Fe adsorbed efectively by adsorbent has particle size 11,5 $\mathrm{nm}$ than adsorbent has particle size 14,5 $\mathrm{nm}$, they are 99,855\% and 100\%, respectively. Reduction metals of Co and Fe decreased $100 \%$ on second adsorption.

Key words: Purification, Absorption, and Adsorbent of $\mathrm{Fe}_{3} \mathrm{O}_{4}$

\section{PENDAHULUAN}

Semakin pesatnya aktivitas perindustrian dewasa ini, berbagai jenis limbah logam berat yang dihasilkan dapat menjadi permasalahan serius bagi kesehatan dan lingkungan. Limbah industri merupakan salah satu jenis limbah yang perlu diperhatikan karena limbah tersebut biasanya mengandung logam berat yang berbahaya bagi kehidupan manusia, seperti Cobalt (Co) dan besi (Fe) [1].

Seiring dengan perkembangan zaman, muncul masalahmasalah terkait limbah industri. Logam besi dan kobalt merupakan logam yang bersifat toksik yang dapat meracuni tubuh manusia dan merusak lingkungan. Menurut KEPMENKES RI No. 907/MENKES/VII/IV/2002 tanggal 29 Juli 2002 tentang syarat-syarat pengawasan kualitas air minum, kadar $\mathrm{Fe}$ dalam air konsumsi yang diperbolehkan yaitu sebesar $0,3 \mathrm{mg} / \mathrm{l}$. Pada air minum yang telah tercemar oleh limbah cair tentu kadar logam yang terkandung melebihi ambang batas dari yang telah ditentukan [2].

Pada umumnya ion limbah logam limbah cair biasanya dihilangkan dengan proses presipitasi, evaporasi, ekstraksi pelarut, pertukaran ion, reverse osmosis, atau separasi membran. Namun hal itu dipercaya bahwa proses presipitasi membutuhkan bahan kimia yang besar dan menghasilkan sampah dalam jumlah besar, sehingga cara ini belum optimal [3].

Berkaitan dengan hal tersebut, pada penelitian ini dilakukan pengolahan limbah yang mengandung $\mathrm{Co}$ dan $\mathrm{Fe}$ dengan metode purifikasi dengan adsorben nanopartikel magnetik $\mathrm{Fe}_{3} \mathrm{O}_{4}$. Metode purifikasi dapat mengabsorpsi limbah Co dan Fe. Proses absorpsi dapat menurunkan kadar logam yang terlarut pada limbah cair dengan cara menyerap logam-logam tersebut ke dalam permukaan absorbennya. Nanopartikel $\mathrm{Fe}_{3} \mathrm{O}_{4}$ merupakan partikel yang memiliki sifat magnetik. Nanopartikel $\mathrm{Fe}_{3} \mathrm{O}_{4}$ sangat tepat dijadikan sebagai adsorben logam karena ukuran partikel yang berada pada skala nanometer memiliki luas permukaan partikel yang besar yang dapat menyerap banyak logam.

Penelitian ini bertujuan untuk menentukan pengaruh konsentrasi $\mathrm{Fe}_{3} \mathrm{O}_{4}$ dalam larutan limbah terhadap tingkat penyerapan logam berat Co dan $\mathrm{Fe}$. Menentukan pengaruh ukuran partikel $\mathrm{Fe}_{3} \mathrm{O}_{4}$ terhadap tingkat penyerapan logam $\mathrm{Co}$ dan $\mathrm{Fe}$, dan menentukan hasil amplifikasi guna untuk mengetahui turunnya kadar logam.

\section{METODE PENELITIAN}

Sintesis nanopartikel $\mathrm{Fe}_{3} \mathrm{O}_{4}$ dilakukan dengan menggunakan metode kopresipitasi. Bahan-bahan yang digunakan untuk sintesis nanopartikel $\mathrm{Fe}_{3} \mathrm{O}_{4}$ ini antara lain $\mathrm{FeSO}_{4} .7 \mathrm{H}_{2} \mathrm{O}$ (Iron (II) sulfate heptahydrate) 4,1703 g, $\mathrm{FeCl}_{3} \cdot 6 \mathrm{H}_{2} \mathrm{O}$ (Iron (III) chloride, hexahydrate) $8.109 \mathrm{~g}, \mathrm{NH}_{4} \mathrm{OH}$ (Ammonia Solution) $10 \% 24 \mathrm{ml}, 4 \%$ dan aquades.

Pembuatan nanopartikel magnetik $\mathrm{Fe}_{3} \mathrm{O}_{4}$ dengan mencampurkan 4,1703 gram $\mathrm{FeSO}_{4} \cdot 7 \mathrm{H}_{2} \mathrm{O}$ dengan 8,109 gram $\mathrm{FeCl}_{3} \cdot 6 \mathrm{H}_{2} \mathrm{O}$ ke dalam $30 \mathrm{ml}$ aquades dan diletakkan di atas magnetik stirer selama 5 sampai 10 menit, dengan perlakuan 
suhu $60^{\circ} \mathrm{C}$ dan kecepatan $450 \mathrm{rpm}$ selama 90 menit sambil ditetesi $\mathrm{NH}_{4} \mathrm{OH}$ sedikit demi sedikit sampai warnanya hitam, kemudian dilakukan pencucian 5-7 kali sampai garamnya hilang, terakhir adalah dipanaskan di dalam furnace . Ketika sudah kering maka sampel nanopartikel $\mathrm{Fe}_{3} \mathrm{O}_{4}$ dihaluskan sampai menjadi serbuk nanopartikel $\mathrm{Fe}_{3} \mathrm{O}_{4}$ [4].

Pembuatan sampel densitas antara nanopartikel $\mathrm{Fe}_{3} \mathrm{O}_{4}$ dengan artificial limbah yaitu masing-masing $0,005 \mathrm{gram} / \mathrm{ml}$, $0,006 \mathrm{gram} / \mathrm{ml}, \quad 0,008 \mathrm{gram} / \mathrm{ml}$, dan $0,01 \mathrm{gram} / \mathrm{ml}$. Pembuatannya dengan cara mencampurkan 0,4 gram $\mathrm{Fe}_{3} \mathrm{O}_{4}$ ke dalam $80 \mathrm{ml}$ artificial limbah, kemudian diletakkan di atas magnet stirer selama 3 jam, dan mengatur pHnya sampai 9 . Selama proses ini, sampel diletakkan di atas magnet permanen 2 kali, masing-masing 30 menit. Kemudian sampel tersebut dikarakterisasi dengan AAS (Atomic Absorbtion Spectroscopy) untuk mengetahui konsentrasi artificial limbah yang terserap oleh absorben nanopartikel magnetikFe $\mathrm{O}_{4}$. Nanopartikel magnetik $\mathrm{Fe}_{3} \mathrm{O}_{4}$ yang digunakan dalam penelitian ini berukuran $14,5 \mathrm{~nm}$.

Dalam eksperimen ini dilakukan pencampuran artificial limbah dengan nanopartikel $\mathrm{Fe}_{3} \mathrm{O}_{4}$ yang memiliki ukuran masing-masing $11,5 \mathrm{~nm}, 14,5 \mathrm{~nm}, 30 \mathrm{~nm}$, dan $80 \mu \mathrm{m}$. Untuk nanopartikel yang berukuran 11,5: mencampurkan 100 $\mathrm{ml}$ artificial limbah dengan 0,5 gram nanopartikel $\mathrm{Fe}_{3} \mathrm{O}_{4}$ di atas magnetik stirer selama 3 jam dan memberikan cairan $\mathrm{NH}_{4} \mathrm{OH}$ sampai pHnya sampai 9. Untuk ukuran nanopartikel berukuran 14,5 nm: mencampurkan $65 \mathrm{ml}$ artificial limbah dengan 0,325 gram nanopartikel $\mathrm{Fe}_{3} \mathrm{O}_{4}$. Untuk ukuran nanopartikel berukuran $30 \mathrm{~nm}$ : mencampurkan $80 \mathrm{ml}$ artificial limbah dengan 0,4 gram $\mathrm{Fe}_{3} \mathrm{O}_{4}$. Untuk ukuran nanopartikel 80 $\mu \mathrm{m}$ : mencampurkan $80 \mathrm{ml}$ artificial limbah dengan 0,4 gram $\mathrm{Fe}_{3} \mathrm{O}_{4}$. Pada eksperimen ini menggunakan parameter yang sama yaitu pada suhu kamar, $\mathrm{pH}$ 9, dan lama pengadukan selama $3 \mathrm{jam}$. Kemudian larutannya disaring menggunakan kertas saring. Kemudian dikarakterisasi dengan menggunakan AAS (Atomic Absorbtion Microscopy)

Hasil pencampuran antara nanopartikel $\mathrm{Fe}_{3} \mathrm{O}_{4}$ berukuran $11,5 \mathrm{~nm}$ dengan artificial limbah yang telah disaring, kemudian diamplifikasi dengan parameter-parameter yang sama yaitu pada temperatur ruang, $\mathrm{pH}$ 9, dan lama pengadukan 3 jam. Kemudian larutannya disaring untuk dikarakterisasi dengan AAS.

\section{HASIL DAN PEMBAHASAN}

\section{Karakterisasi Nanopartikel Magnetik $\mathrm{Fe}_{3} \mathrm{O}_{4}$}

Berdasarkan hasil analisis pola difraktogram nanopartikel magnetik yang ditunjukkan pada Gambar 1 menunjukkan indikasi terbentuknya fasa $\mathrm{Fe}_{3} \mathrm{O}_{4}$ di dalam sampel hasil sintesis nanopartikel $\mathrm{Fe}_{3} \mathrm{O}_{4}$. Indikasi tersebut didasarkan pada nilai parameter kekisi yang telah diestimasi dari sudut $2 \theta=35,68^{\circ}$ yaitu pada puncak difraksi utama dengan indek (311). Dari hasil tersebut juga diketahui nilai parameter kekisi 8,32 Å dan jarak antar bidang kristalnya 2,51 $\AA$. Pada nilai parameter kekisi 8,324 ̊̊ mendekati nilai parameter referensi kekisi $\mathrm{Fe}_{3} \mathrm{O}_{4}$ dalam bentuk bulk $(8,4 \AA)$ [5]. Indikasi yang menunjukkan fasa $\mathrm{Fe}_{3} \mathrm{O}_{4}$ adalah adanya puncak-puncak difraksi indeks miller lain seperti (220), (400), (511), dan (440). Adanya puncak-puncak indeks miller tersebut menunjukkan indeks khas dari struktur spinel $\mathrm{Fe}_{3} \mathrm{O}_{4}$ yang biasa muncul dalam difraktogram XRD bahan $\mathrm{Fe}_{3} \mathrm{O}_{4}$.

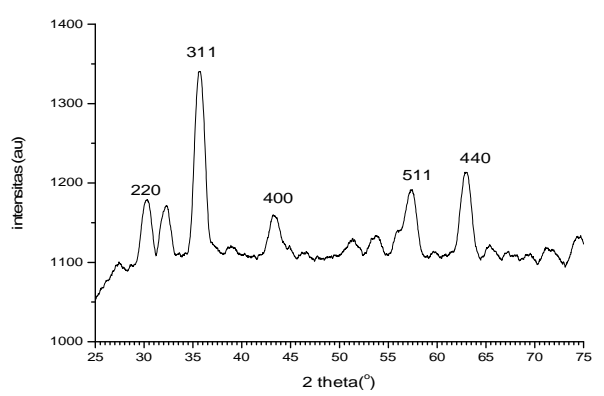

Gambar 1. Hasil XRD Nanopartikel $\mathrm{Fe}_{3} \mathrm{O}_{4}[7]$

Hasil karakterisasi TEM pada nanopartikel $\mathrm{Fe}_{3} \mathrm{O}_{4}$ diperoleh bentuk morfologi $\mathrm{Fe}_{3} \mathrm{O}_{4}$ yang bulat dengan diameter nanopartikel yang beragam. Bentuk morfologi dari nanopartikel $\mathrm{Fe}_{3} \mathrm{O}_{4}$ dapat ditunjukkan pada Gambar 2 .

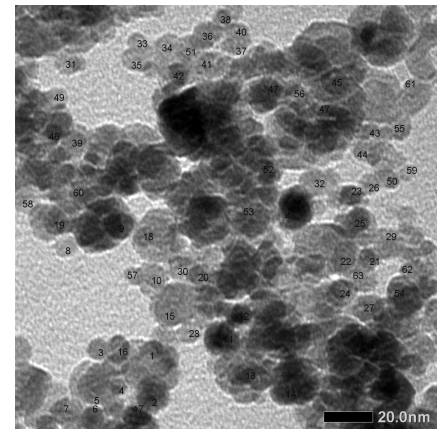

Gambar 2. Morfologi Nanopartikel Magnetik $\mathrm{Fe}_{3} \mathrm{O}_{4}$ [7]

Dari hasil TEM dapat dihitung diameter masingmasing partikel menggunakan software ImageJ . Hasil perhitungan masing-masing partikel kemudian dapat dibuat distribusi partikelnya menggunakan Kaleidagraph. Distribusi nanopartikel $\mathrm{Fe}_{3} \mathrm{O}_{4}$ ditunjukkan pada Gambar 3. Pada Gambar 3 diperoleh hasil $10 \mathrm{~nm}$. 


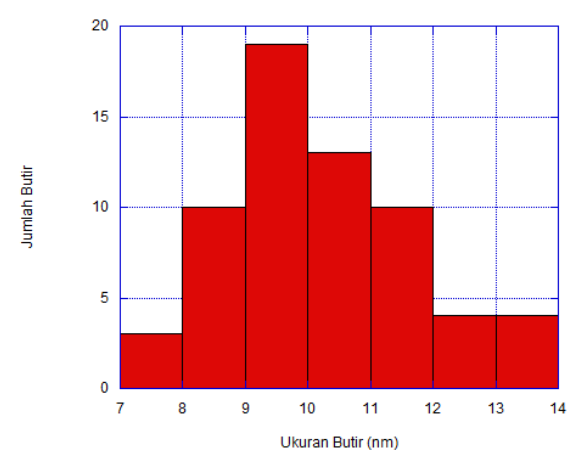

Gambar 3. Distribusi Ukuran Diameter nanopartikel magnetik $\mathrm{Fe}_{3} \mathrm{O}_{4}$

Gambar 4. menunjukkan kurva loop histerisis nanopartikel magnetik $\mathrm{Fe}_{3} \mathrm{O}_{4}$. Pengukuran sifat magnet melalui bentuk kurva loop histerisis memberikan informasi bahwa nanopartikel magnetik $\mathrm{Fe}_{3} \mathrm{O}_{4}$ yang disintesis ini mempunyai sifat superparamagnetik, hal ini dapat dilihat dari bentuk kurvanya yang menyerupai kurva superparamagnetik. Sampel $\mathrm{Fe}_{3} \mathrm{O}_{4}$ memiliki medan koersif 45,7 Oersted, magnetisasi remanen sebesar 7,846 emu/g, dan magnetisasi saturasi $\left(M_{s}\right)$ sebesar 76,99 emu/g. Sifat superparamagnetik dari nanopartikel $\mathrm{Fe}_{3} \mathrm{O}_{4}$ membuatnya sangat rentan terhadap medan magnet luar, hal ini dapat dilihat pada kurva dengan memberikan sedikit medan magnet nanopartikel dapat mengalami magnetisasi saturasi. Dengan sifat yang mudah termagnetisasi maka nanopartikel $\mathrm{Fe}_{3} \mathrm{O}_{4}$ merupakan material soft magnetik.

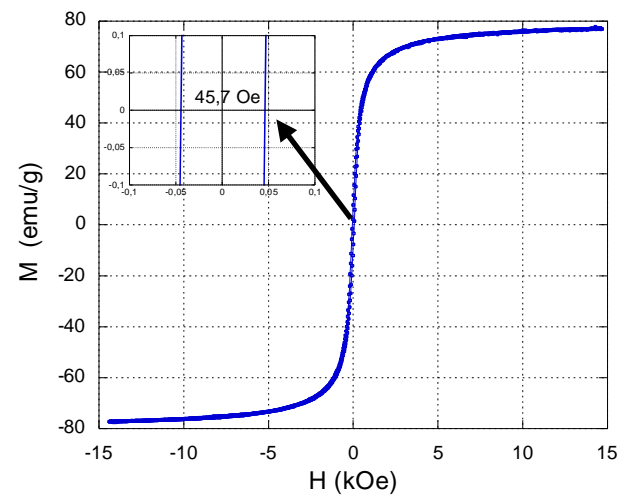

Gambar 4. Kurva loop histerisis $\mathrm{Fe}_{3} \mathrm{O}_{4}[7]$

\section{Pengaruh Konsentrasi absorben $\mathrm{Fe}_{3} \mathrm{O}_{4}$ terhadap Presentase Penurunan Kadar logam Co dan $\mathrm{Fe}$}

Tabel 1. Menunjukkan hasil pengujian pengaruh variasi konsentrasi absorben $\mathrm{Fe}_{3} \mathrm{O}_{4}$ terhadap presentase penurunan kadar logam Co dan Fe.

Tabel 1. Pengaruh Konsentrasi adsorben $\mathrm{Fe}_{3} \mathrm{O}_{4}$

Semakin besar konsentrasi $\mathrm{Fe}_{3} \mathrm{O}_{4}$ menunjukkan tingkat penyerapan $\mathrm{Fe}_{3} \mathrm{O}_{4}$ terhadap Co dan $\mathrm{Fe}$ semakin besar. Hal ini bisa terjadi karena tumbukkan antara absorben dengan absorbet. $\mathrm{Fe}_{3} \mathrm{O}_{4}$ sebagai absorben memiliki peran menyerap limbah $\mathrm{Co}$ dan $\mathrm{Fe}$ dengan cara menyerap logam-logam tersebut ke dalam permukaan absorbennya. Nanopartikel

\begin{tabular}{|c|c|c|c|c|c|}
\hline \multirow[b]{2}{*}{$\begin{array}{l}\mathrm{N} \\
\mathrm{O}\end{array}$} & \multirow[b]{2}{*}{$\begin{array}{l}\text { Para } \\
\text { meter }\end{array}$} & \multirow{2}{*}{$\begin{array}{l}\text { Row } \\
\text { material } \\
\text { (A) }\end{array}$} & & \multicolumn{2}{|c|}{ Konsentrasi $\mathrm{Fe}_{3} \mathrm{O}_{4}$} \\
\hline & & & & $\begin{array}{c}0,008 \\
\mathrm{~g} / \mathrm{ml}\end{array}$ & $\begin{array}{l}0,01 \\
\mathrm{~g} / \mathrm{ml}\end{array}$ \\
\hline \multirow[b]{2}{*}{1} & \multirow[b]{2}{*}{ Co } & \multirow[b]{2}{*}{1058,073} & $\begin{array}{c}\text { Rata- } \\
\text { rata }\end{array}$ & 455,399 & 302,816 \\
\hline & & & $\begin{array}{l}\text { Persenta } \\
\text { se } \\
\text { penurun } \\
\text { an }(\%)\end{array}$ & 56,959 & 71,380 \\
\hline \multirow[b]{2}{*}{2} & \multirow[b]{2}{*}{$\mathrm{Fe}$} & \multirow[b]{2}{*}{1501,603} & $\begin{array}{l}\text { Rata- } \\
\text { rata }\end{array}$ & 0,551 & 0,122 \\
\hline & & & $\begin{array}{l}\text { Persenta } \\
\text { se } \\
\text { penurun } \\
\text { an }(\%)\end{array}$ & 99,963 & 99,991 \\
\hline
\end{tabular}

$\mathrm{Fe}_{3} \mathrm{O}_{4}$ sebagai material magnetik yang memiliki ukuran partikel yang berada pada skala nanometer memiliki luas permukaan partikel besar dapat menyerap banyak logam berat Co dan Fe. Sementara Co dan Fe juga merupakan material yang bersifat magnetik. Saat limbah bertumbukan dengan absorben, absorbet menempel pada permukaan absorben dan limbah Co dan Fe tidak dilepaskan lagi. Waktu pengadukan antara ion logam dengan absorben merupakan parameter yang penting untuk mengetahui kecepatan reaksi absorpsi. Semakin sedikit waktu interaksi, laju reaksi makin cepat yang berarti juga laju absorpsi makin tinggi [6].

\section{Pengaruh Ukuran butir adsorben $\mathrm{Fe}_{3} \mathrm{O}_{4}$ terhadap Presentase Penurunan Kadar logam Co dan Fe}

Tabel 2. Menunjukkan hasil pengujian pengaruh variasi ukuran partikel absorben $\mathrm{Fe}_{3} \mathrm{O}_{4}$ terhadap presentase penurunan kadar logam Co dan $\mathrm{Fe}$

Tabel 2. Pengaruh ukuran partikel absorben $\mathrm{Fe}_{3} \mathrm{O}_{4}$ 
Berdasarkan Tabel 2 menunjukkan bahwa semakin kecil ukuran partikel menyebabkan kadar penurunan Co dan Fe semakin besar. Ini disebabkan karena ukuran partikel absorben $\mathrm{Fe}_{3} \mathrm{O}_{4}$ memiliki ukuran partikel berada pada skala nanometer dan memiliki luas permukaan partikel besar yang menyerap banyak logam. Hal ini menunjukkan bahwa ukuran partikel absorben $\mathrm{Fe}_{3} \mathrm{O}_{4}$ yang lebih kecil mampu mengabsorbsi logam Co dan Fe lebih besar.

Pengaruh Amplifikasi pada Penurunan Kadar Logam Fe

\begin{tabular}{|c|c|c|c|c|c|}
\hline \multirow[t]{2}{*}{$\begin{array}{l}\mathrm{N} \\
\mathrm{O}\end{array}$} & \multirow{2}{*}{$\begin{array}{l}\text { Para } \\
\text { meter }\end{array}$} & \multirow{2}{*}{$\begin{array}{c}\text { Raw } \\
\text { material } \\
\text { (A) }\end{array}$} & & \multicolumn{2}{|c|}{$\begin{array}{c}\text { Ukuran butir } \\
\text { absorben } \mathrm{Fe}_{3} \mathrm{O}_{4}\end{array}$} \\
\hline & & & & $14,5 \mathrm{~nm}$ & $11,5 \mathrm{~nm}$ \\
\hline \multirow[b]{2}{*}{1} & \multirow[b]{2}{*}{ Co } & \multirow[b]{2}{*}{1058,073} & Rata-rata & 1,654 & 1,533 \\
\hline & & & $\begin{array}{c}\text { Persenta } \\
\text { se } \\
\text { penuruna } \\
\mathrm{n}(\%)\end{array}$ & 99,843 & 99,855 \\
\hline \multirow[b]{2}{*}{2} & \multirow[b]{2}{*}{$\mathrm{Fe}$} & \multirow[b]{2}{*}{1501,603} & Rata-rata & 0,133 & 0 \\
\hline & & & $\begin{array}{c}\text { Persenta } \\
\text { se } \\
\text { penuruna } \\
\mathrm{n}(\%)\end{array}$ & 99,991 & 100 \\
\hline
\end{tabular}

dan Co dalam Artificial Limbah

Tabel 3. Pengaruh Amplifikasi

\begin{tabular}{|c|c|c|c|c|c|}
\hline \multirow[b]{2}{*}{$\begin{array}{l}\mathrm{N} \\
\mathrm{O}\end{array}$} & \multirow{2}{*}{$\begin{array}{c}\text { Param } \\
\text { eter }\end{array}$} & \multirow{2}{*}{$\begin{array}{c}\text { Raw } \\
\text { material }\end{array}$} & & \multicolumn{2}{|c|}{ Adsorbsi } \\
\hline & & & & Pertama & Kedua \\
\hline \multirow[t]{2}{*}{1} & \multirow[t]{2}{*}{$\mathrm{Co}$} & \multirow[b]{2}{*}{1058,073} & Rata-rata & 1,540 & 0 \\
\hline & & & $\begin{array}{l}\text { Presentase } \\
\text { penurunan } \\
(\%)\end{array}$ & 99,854 & 100 \\
\hline \multirow[t]{2}{*}{2} & \multirow[b]{2}{*}{$\mathrm{Fe}$} & \multirow[b]{2}{*}{1501,603} & Rata-rata & 0 & 0 \\
\hline & & & $\begin{array}{l}\text { Presentase } \\
\text { penurunan } \\
(\%)\end{array}$ & 100 & 100 \\
\hline
\end{tabular}

Amplifikasi (pengulangan) merupakan parameter penting yang digunakan dalam proses penyerapan logam. Pengujian amplifikasi dilakukan sebanyak dua kali dengan perlakuan $\mathrm{pH} 9$ dan waktu pengadukan 3 jam untuk setiap sampel. Dari hasil analisis SSA yang ditampilkan pada Tabel 3 diperoleh hasil logam $\mathrm{Co}$ dan $\mathrm{Fe}$ mengalami penurunan kadar logam maksimal pada amplifikasi ke dua yaitu mencapai $100 \%$. Hal ini menunjukkan bahwa semakin banyak proses pengulangan mengakibatkan konsentrasi penurunan logam Fe dan Co semakin besar.

\section{Kesimpulan}

Berdasarkan hasil penelitian yang telah dilakukan dapat disimpulkan bahwa adsorben nanopartikel $\mathrm{Fe}_{3} \mathrm{O}_{4}$ mampu menurunkan kadar logam Co dan Fe dalam artificial limbah.
Penurunan kadar logam Co dan Fe terjadi pada konsentrasi $\mathrm{Fe}_{3} \mathrm{O}_{4} \quad 0,01 \mathrm{~g} / \mathrm{ml}$ yaitu $\mathrm{Co} 71,38 \%$ dan $\mathrm{Fe} 99,991 \%$. Penurunan kadar logam Co dan Fe terserap secara maksimal terjadi pada ukuran partikel $\mathrm{Fe}_{3} \mathrm{O}_{4}$ 11,5 nm yaitu $\mathrm{Co} 99,855 \%$ dan $\mathrm{Fe} 100 \%$. Pengaruh amplifikasi mampu menjadikan nanopartikel $\mathrm{Fe}_{3} \mathrm{O}_{4}$ dalam menyerap logam $\mathrm{Fe}$ dan Co secara signifikan.

\section{PUSTAKA}

[1] Siti Wardiyati dkk, Adsorpsi Ion $\mathrm{Pb}^{2+}$ dan $\mathrm{Ni}^{2+}$ oleh Nanopartikel $\gamma-\mathrm{Fe}_{2} \mathrm{O}_{3} / \mathrm{Fe}_{3} \mathrm{O}_{4}, 2007$.

[2] Andreas, D.P. dan Ali, M, Penurunan Kadar Besi oleh Media Zeolit Alam Ponorogo Secara Kontinyu, Jurusan Teknik Lingkungan FTSP-ITS, 2004.

[3] Y.F. Shen.etc, Tailoring Size and Structural Distortion of $\mathrm{Fe}_{3} \mathrm{O}_{4}$ nanoparticles for the purification of Contaminated water, Biosource Technology, 2009.

[4] Jing Sun.etc, Synthesis and Characterization of Biocompatible $\mathrm{Fe}_{3} \mathrm{O}_{4}$ Nanoparticles, Wiley InterScience DOI:10.1002/jbm.a.30909, 2006.

[5] Coey, J.M.D, Magnetism and Magnetic Materials, United States of America, Cambridge University Press, 2009.

[6] Feng Huixia.etc, Preparation and Characterization of the Cobalt Ferrite Nano-Particles by reverse Coprecipitation, Journal of Magnetism and Magnetic Materials, 2013.

[7] Seveny Nuzully, Karakteristik Sifat Kemagnetan Pada Polyethlene Glicol (PEG) Coated Nanopartikel Magnetite $\left(\mathrm{Fe}_{3} \mathrm{O}_{4}\right)$ untuk Pengikat DNA, Tesis, 2013. 